\title{
Enhancing customer-based brand equity through CSR in the hospitality sector
}

\author{
Patricia Martínez García de Leaniz \\ University of Cantabria \\ Faculty of Business Sciences and Economics \\ Avenida de los Castros s/n, Santander \\ 39005 (Spain) \\ martinezrp@unican.es \\ Noriaki Nishiyama \\ Hokkaido University \\ Center for Advanced Tourism Studies \\ Kita-17, Nishi-8. Kita-ku, Sapporo \\ Hokkaido 060-0817 (Japan) \\ nishiyama@cats.hokuda.ac.jp
}




\section{Enhancing customer-based brand equity through CSR in the hospitality sector}

Corporate social responsibility is considered an important element in the development of brand equity. Extant research in this context is mainly focused on the relationship between this corporate philosophy and financial performance, overlooking its potential to develop competitive advantages through brand equity dimensions. The aim of this research is to explore the impact of socially responsible aspects on hotel brand equity. To test the proposed model personal surveys of hotel customers were conducted. A structural equation model was developed to test the research hypotheses. The findings show that corporate social responsibility has positive effects on brand image, perceived quality, brand awareness and brand loyalty.

\section{Keywords}

Corporate social responsibility, customer-based brand equity, brand image, brand loyalty, perceived quality, brand awareness, hospitality 


\section{Introduction}

The hospitality industry is seeing exceptional growth after the global economic recession. The American Hotel \& Lodging Association manifests that this industry generated \$41 billion income worldwide in 2014 which represents an increase of $10.2 \%$ over 2012. In the same period of time, total industry revenue was $\$ 163$ billion which corresponds to an increase of 5.4\% from 2012. Meanwhile, hotel firms are also facing fierce competition particularly with the favorable evolution of alternative lodging products such as services apartments, hostels and apartment rentals (Ernst \& Young, 2014). This growth in hospitality revenue reveals guests' increasing interest in the lodging context, but it also indicates the need for these companies to differentiate themselves from their competitors to increase their revenues attracting customers (Tsai, Cheung \& Lo, 2010). In this sense, one of the most effective ways to differentiate a hospitality company is to create a wellknow brand and develop effective branding strategies (Dev, 2012).

The building of strong brands for hotel firms is crucial given the intangibility of hospitality services and the subjective perception of the quality of hotel services (Martínez \& Rodríguez del Bosque, 2013). It is accepted that a distinguished brand can create competitive advantages in the hotel sector (Jiang, Dev \& Rao, 2002). It is also argued that customers understand brands as an implicit promise of the level of service they are going to receive (Yesawich, 1996). A hotel brand behaves as a symbol of customers' perceptions of hotel companies and their services (Kim \& Kim, 2005). With regard to this, hotel brands have different meanings in the minds of customers. For instance, Hilton hotels are based on an atmosphere of opulence whereas Meliá hotels are based on concepts such as service vocation, innovation and proximity (Martínez, Pérez \& Rodríguez del Bosque, 2014a).

The value of a brand to companies and consumers has been defined as "brand equity" and many authors consider it as the most valuable asset (Herrmann, Huber, Shao \& Bao, 2007). In the hospitality industry the research about brand equity issues has gained attention over the last years (Hsu, Hung \& Tang, 2012; Huan \& Cai, 2015; Seric, GilSaura \& Ruiz-Molina, 2014). With this relevance in brand equity, it is evident that hospitality literature must include this concept as a central aspect in corporate strategies and must also include its drivers. In their request, Keller and Lehman (2006) claim that it is necessary to further explore brand equity and its antecedents with the aim of understanding the concept. However, there is no consensus in the hospitality literature on how brand equity is built in the hotel industry (Kayaman \& Arasli, 2007; So \& King, 2010; Xu \& Chan, 2010). Extant research suggests that corporate social responsibility (CSR) can build brand equity (Creel, 2012; Khan \& Mandawi, 2013; Namkung \& Jang, 2013). Nevertheless, past studies have not explored the influence of CSR on brand equity in the hospitality context.

Recent studies propose that brand equity shares many elements with CSR. CSR means that organizations take on responsibility toward others in society, not only on their shareholders and customers (Holloway, 2004). Actually, many CSR issues can increase 
the level of brand equity of companies (Crees, 2012). An instance could be the development of social programs to help local communities where companies operate such as hiring local employees or supporting local business. Additional practices could focus on environmental issues such as the mitigation of the effects of climate change, reduction in the consumption of water or protection of environmentally valuable habitats. These initiatives would help firms improve not also their brand image and awareness but also other brand equity drivers. With regard to this, scholars suggest that hospitality companies should integrate a socially responsible orientation into their corporate strategies to diminish the harmful effects of their activities on the natural environment and local communities (Martínez \& Rodríguez del Bosque, 2013).

Even though consumers' attitudes and behavioral intentions toward hospitality companies implementing CSR practices have been previously explored (Martínez \& Rodríguez del Bosque, 2013; Swimberghe \& Wooldridge, 2014) the effects of CSR on brand equity antecedents have to be investigated. To fill this gap this study attempts to answer the following research question: Do CSR in hospitality companies influence customer-based brand equity (CBBE) development? This study intends to fill this existing gap by empirically testing the influence of CSR on the creation of CBBE dimensions.

As it will be explained in the next section the CBBE notion addresses the brand equity from the perspective of customers. In order to fulfill this research objective four equity dimensions were found significant in the hospitality industry: perceived quality, brand image, brand awareness and brand loyalty. Therefore this study conceptualizes CBBE as a combination of aspects related to customers' perceptions (e.g., brand image, brand awareness and perceived quality) and customers' behavior (e.g., brand loyalty).

The structure of this study is as follows. A literature review is discussed in the first section. Then, the sample research, data collection method and measurement scales are explained. After that, it is presented the reliability and validity of the measurement scales and the findings of the theoretical model. Finally, this research discusses finding and managerial implications and points out possible lines for future research.

\section{Conceptual framework}

\section{CSR studies in the hospitality industry}

Although CSR is one of the most prominent concepts in the tourism and hospitality literature it is used widely and loosely (Font, Walmsley, Cogotti, McCombes \& Hausler, 2012). Scholars and practitioners find it difficult to provide a precise definition of the concept. However, there is consensus among researchers that CSR implies that firms have responsibilities towards society that exceed shareholder wealth maximization. Socially responsible companies contemplate "the full scope of their impacts on communities and the environment when making decisions, balancing the needs of stakeholders with their needs to make a profit” (Nicolau, 2008, p. 991). Furthermore, several scholars propose that the characteristics of the tourism industry add an additional dimension to socially responsible strategies in this context because local communities and the natural 
environment are part of the tourist product (Henderson, 2007). If used in a responsible way tourism (including hospitality business) can be a source of economic growth (Doods \& Kuehnel, 2010). It can help to create employment, provide infrastructures and improve cultural understanding. However, if used irresponsibly tourism can also be a source of environmental degradation, dilution of cultural identity or traditions and displacement of local people. As Martínez and Rodríguez del Bosque (2013) indicate these are issues for hospitality firms to improve social and natural environments by including CSR aspects into their corporate strategies.

The existing literature on CSR in the hospitality industry has focused on the relationship between CSR and financial performance (Inoue \& Lee, 2011; Kang, Lee \& Huh, 2010; Lee, Singal \& Kang, 2013; Park \& Lee, 2009; Singal, 2014; Tsai et al., 2010; Wang, 2014), CSR reporting (De Grosbois, 2010; Font et al., 2012; Holcomb, Upchurch \& Okumus, 2007; Hsieh, 2012; Nyahunzvi, 2013), the expectations and perceptions of CSR among customers and employees (Kucukusta, Mak \& Chan, 2013; Park \& Levy, 2014; Tsai, Tsang \& Cheng, 2012; Xu, 2014), the importance of different CSR practices among managers (Geerts, 2014; Gu \& Ryan, 2011) and the CSR initiatives implemented in this industry (Bohdanowicz \& Zientera, 2008; Chung \& Parker, 2010). Some studies have also explored the reasons behind CSR strategies (Ayuso, 2006; Garay \& Font, 2012). As an example, some reasons for implementing CSR practices are cost savings, pressure from customers and personal awareness (Ayuso, 2006). Similarly, past studies have analyzed the influence of CSR on customers' and employees' behavior (Ben, Ye \& Law, 2014; Liu, Wong, Rongwei \& Tseng, 2014; Martínez \& Rodríguez del Bosque, 2013; Raub \& Blunschi, 2014; Swimberghe \& Wooldridge, 2014; Wells, Manikab, GregorySmith, Taherid \& McCowlene, 2015). For instance, Martínez and Rodríguez del Bosque (2013) explore the influence on hotel customer loyalty by including customer trust, identification with the company and satisfaction as mediating variables. Similarly, Liu et al. (2014) investigate how CSR perceptions influence customers' preference and loyalty. On the other hand, Ben et al. (2014) explore hotel employees' perceptions of CSR and their impact on their behavior.

It must be highlighted that previous studies on CSR issues in the hospitality industry have not explored the effects of CSR in association with brand equity antecedents. To the best of the authors' knowledge, no prior studies have analyzed the role that CSR may play in the creation of CBBE. Consequently, this research attempts to bridge this gap by investigating how CBBE dimensions can be developed through CSR practices.

\section{Customer-based brand equity in the hospitality industry}

Branding has become a relevant issue in the hospitality industry and an indispensable element for hotel firms. For instance, Hilton hotels established the brand name "Hilton" to identify its properties and nowadays there is considerable identification of the name "Hilton" with high-end lodging. On the other hand, the Meliá group, initially under the name of "Sol Meliá", changed its brand name to "Meliá Hotels International" in order to obtain a more stable corporate image and emphasize the globalism of the firm (Martínez 
et al., 2014a). Nevertheless, the drivers and management of brand equity remain uncertain in the hospitality industry (Xu \& Chan, 2010).

The term of brand equity can be defined as "a set of brand assets and liabilities linked to a brand, its name and symbol that add to or subtract from the value provided by a product or service to a firm and/or to that firm's customers" (Aaker, 1991, p. 15). Three theoretical perspectives have been adopted to understand this concept: (1) the financial perspective, (2) the customer perspective and (3) a combination of these two conceptualizations (Kim \& Kim, 2005). Financial-based brand equity investigates the additional value that a brand name adds to a company (compared to an unbranded competitor) (Farquhar, 1989). On the other hand, CBBE concept addresses the brand equity from the perspective of customers. This perspective reflects the strength of a brand in customers' mind (Huan \& Cai, 2015). Keller (1998, p. 8) defined customer brand equity as "the difference effect of brand knowledge on consumer response to the marketing of the brand".

Numerous studies show the interest aroused by the CBBE research area in the hospitality context (e.g., Bose, Roy \& Tiwari, 2015; Çifci, Ekinci, Whyatt, Japutra, Molinillo \& Siala, 2016; Huan \& Cai, 2015; Seric \& Gil-Laura, 2012; Seric et al., 2014; So \& Kim, 2010; Xu \& Chan, 2010). CBBE has been linked to desirable corporate outcomes such as increased market share and profitability, enhanced brand extension, increased consumer preferences and purchase intentions, consumers' willingness to pay premium prices, enhanced brand reputation, better marketing communications and added value to both companies and their consumers (Kimpakorn \& Tocquer, 2010; Wong \& Wickham, 2015).

The majority of studies on CBBE research in the hospitality literature are based on the conceptual papers of Aaker and Keller (Aaker, 1991, 1996; Keller, 1993, 1998). Specifically, the conceptualization provided by Aaker $(1991,1996)$ is the most frequently applied within this industry. Aaker identified five equity dimensions: (1) brand associations (brand image), (2) perceived quality, (3) brand awareness, (4) brand loyalty and (5) other proprietary brand assets (e.g., patents and trademarks). However, Yoo and Donthu (2001) demonstrated that the last dimension is not relevant to consumers' perception because CBBE represents the assessment of cognitive and behavioral brand equity through customer surveys.

Several hospitality researchers have conducted CBBE research in the hotel industry. For instance, Prasad and Dev (2000) developed a customer index of hotel brand equity considering customers as the source of profits. Kayaman and Arasli (2007) examined the relationships among brand equity dimensions. Xu and Chan (2010) provided a conceptual framework for understanding CBBE categorizing the concept into its attitudinal and behavioral aspects. So and King (2010) developed a measure to evaluate brand equity as an outcome of brand strategies. Hsu et al. (2012) described a model to build a servicebased brand equity that takes into account both customer value and business strategy. Huang and Cai (2015) developed a CBBE model examining the effects of brand knowledge on consumer responses to brands. 
As previously mentioned, research on CBBE in hospitality businesses suggest that brand equity is a multi-dimensional concept comprised of four components: brand image, perceived quality, brand awareness and brand loyalty (Denizci \& Tasci, 2010; Kayaman \& Arasli, 2007; Kim \& Kim, 2004; Kim \& Kim, 2005; Kim, Kim \& An, 2003; Kim, JinSun \& Kim, 2008; Hyun \& Kim, 2001, Seric \& Gil-Laura, 2012; Seric et al., 2014; Tsai et al., 2010; Xu \& Chan, 2010). These dimensions are defined below.

Firstly, brand image (or brand associations) is "anything that is linked in memory to a brand" (Aaker, 1991, p. 147). In the hospitality context the image that customers have of a hotel plays a key role in their decisions and is one of the most important factors that influence guests' choices and future behavioral intentions (Kandampully \& Suhartanto, 2000). A favorable and recognized brand image is a valuable asset since it has an impact not only on customers' perceptions of corporate communications but also on the operations of the firm (Kang \& James, 2004). According to Xu and Chan (2010), the hotel brand image consists of the hotel's physical appearance, logo, category (e.g., star rating), corporate reputation, history, price range and even location and country of origin. Secondly, perceived quality is considered as a core element of customer brand equity (Aaker, 1996; Keller, 1993). Although there is no consensus about the conceptualization and measurement of this term, it has been proposed that it is "the customer's judgment about a product or service's overall excellence or superiority" (Zeithaml, 1988, p. 3). It has been postulated that the level of perceived quality determines the level of brand equity (Yoo et al., 2000). Furthermore, perceived quality is a key reason why customers buy a brand and differentiate it from rival firms (Herrmann et al., 2007; Namkung \& Jang, 2013).

Thirdly, brand awareness is "the ability for a buyer to recognize or recall that a brand is a member of a certain product category" (Aaker, 1991, p.61). According to Aaker (1991), the creation of brand awareness is the first step in building brand equity. Brand awareness represents customers' ability to recognize a distinctive image under varying conditions of complexity and time pressure (Hsu et al., 2012). This construct can influence customers' purchasing decision by eliminating competing brands from consideration (Wong \& Wickham, 2015). Fourthly, it has been suggested that brand loyalty is a determining factor of CBBE as well as a strategic asset for companies (Aaker, 1991). Brand loyalty can be defined as "the attachment that a customer has to a brand" (Aaker, 1991, p. 65). Previous research suggests two dimensions of brand loyalty: attitudinal loyalty and behavioral loyalty (Jones \& Taylor, 2007). Attitudinal loyalty refers to the dispositional attitude or commitment a consumer has toward a brand. In the context of this research, attitudinal brand loyalty would be manifested by positive feelings towards a hotel company. On the other hand, behavioral loyalty refers to the frequency of repeat purchase of same brand purchase. In the hospitality context, behavioral brand loyalty would be manifested by repeated stays in a hotel brand. Based on the previous ideas, this study proposes a research framework for the formation of CBBE derived from CSR aspects.

\section{The impact of CSR on customer-based brand equity dimensions}


Previous studies have suggested that CSR strategies can build brand equity (Aldás, Andreu \& Currás, 2013; Chen \& Myagmarsuren, 2011; Creel, 2012; Hur, Kim \& Woo, 2014; Khan \& Manwani, 2013; Namkung \& Jang, 2013; Wang, Chen, Yu \& Hsiao, 2015). When building brand equity a company must understand the value systems of its customers, especially regarding the preference of customers in relation to CSR (Creel, 2012). In this sense, Jones (2005) indicates that brand equity is co-created through the interaction with multiple stakeholders (including customers). In simple terms, the more satisfied the stakeholders' expectations, the more valuable the brand equity. Given the negative impacts of hospitality companies on natural, social and cultural environments, socially responsible behavior is one of the most demanded expectations (Henderson, 2007; Nicolau, 2008). Following these ideas, this study assumes that CSR perceptions about hotels can positively increase their level of brand equity because these perceptions induce customers' favorable brand awareness and image, improve their level of perceived quality about hotel services and create brand loyalty.

Regarding the relationship between CSR and brand image previous studies suggest that customers' purchasing decisions are not only influenced by tangible aspects such as usage or price range, but also by intangible (symbolic) attributes such as brand associations and image (Bekk, Sp, Hedjasie \& Kerschreiter, 2016; He \& Lai, 2014; Martínez et al., 2014a). These emotional features are linked with a psychological dimension manifested through diverse feelings and attitudes towards firms (Kennedy, 1977). As He and Lai (2014, p. 252) explain, these symbolic features "reflect consumers' social approval and selfexpression". CSR activities provide valuable content to brand associations because they connect companies with ethical values such as honesty, respect or sustainability (Martínez et al., 2014a). Hence, socially responsible practices, as an emotional aspect of brand image, are key sources to enhance brand equity. These considerations lead the authors to propose the following hypothesis:

$\mathbf{H}_{1}$ : CSR has a positive impact on brand image.

CSR and perceived quality are relevant management approaches in the hospitality industry to be able to generate a sustainable competitive advantage. Both approaches focus on identifying customers' needs and claims, and have common principles such as the importance of creating trust, honesty and mutual benefits when developing relationships (Benavides-Velasco, Quintana-García \& Marchante-Lara, 2014). Following this line of thought, some academics conceptualize CSR as a quality improvement being an integral component of strategy formulation (McWilliams \& Siegel, 2001). By integrating CSR initiatives into their corporate strategies firms can enhance customers' judgments about their service's overall distinction, thus enhancing perceived quality (Hermann et al., 2007). For instance, according to Brown and Dacin (1997) a primary support from customers of a socially responsible company is a positive attitude toward the company, which leads to positive product and service quality perceptions. Actually, since hospitality services cannot be realized before consumption, perceived CSR initiatives can be used to signal product/service quality and to influence consumer perceptions (Brown \& Dacin, 1997). CSR initiatives indicate something about the quality 
of products/services since they create associations in the mind of customers (Keller \& Lehmann, 2006). In this sense, CSR creates an image that a firm is reliable and honest. Consumers typically assume that products/services of a reliable and honest company will be of high quality (Benavides-Velasco et al., 2014; McWilliams, Siegel \& Wright, 2005). Therefore, the following hypothesis is proposed:

$\mathbf{H}_{2}$ : CSR has a positive impact on perceived quality.

Concerning the relation between CSR and brand awareness there is substantial literature suggesting that CSR activities can enhance brand awareness (Aldás et al., 2013; Lai et al., 2009; Servaes \& Tamayo, 2013; Tian, Wang \& Yang, 2011; Zhang, 2014). For instance, Lai et al. (2009) demonstrate that the perception of a socially responsible behavior induces customers' positive brand awareness. By developing a socially responsible behavior firms can increase customers' ability to recognize their brand and differentiate themselves from competitors. The problem here is that customers are often not aware of CSR practices. This lack of customers' awareness about CSR activities is a major limiting factor in their ability to create brand equity and respond to these initiatives. That is the reason why many hotels make great efforts to raise CSR awareness among their consumers (Kucukusta et al., 2013). Therefore, the authors propose the following hypothesis:

$\mathbf{H}_{3}$ : CSR has a positive impact on brand awareness.

In respect to the relationship between CSR and brand loyalty previous studies suggest that CSR initiatives can be positively related with brand loyalty in terms of attitudinal and behavioral aspects (He \& Lai, 2014; He \& Li, 2011; Martínez, Pérez \& Rodríguez del Bosque, 2014b; Shobri, Diyana \& Lennora, 2015). These studies propose that CSR directly creates loyalty towards the company (or the brand) without needing mediating variables. According to these researchers, socially responsible initiatives are such a relevant and significant aspect of brand image that are able to directly attract customers. Marin, Ruiz and Rubio (2009) argue that the perception of a socially responsible behavior strengthens brand loyalty as it shows a personality and a set of principles and values that demonstrate respect towards customers and society, this enhancing brand loyalty. Therefore, the following hypothesis is proposed:

H4: CSR has a positive impact on brand loyalty.

Furthermore, the literature review reveals the relationships existing among the four equity dimensions significant in the hotel industry. Therefore, extant research has empirically demonstrated that perceived quality can influence brand image (Kandampully \& $\mathrm{Hu}$, 2007; Kayaman \& Arasli, 2007; Seric et al., 2014) and brand loyalty (Chen \& Myagmarsuren, 2011; He \& Lai, 2014; Hyun \& Kim, 2011; Martínez et al., 2014b). In a similar way, the impact of perceived quality on brand awareness (Denizci \& Tasci, 2010; Kayaman \& Arasli, 2007) and brand loyalty have also been proved (Chen \& Myagmarsuren, 2011; Hsu et al., 2012; Kandampully, Juwaheer \& Hu, 2011; Kayaman \& Arasli, 2007; Seric et al., 2014). Moreover, other studies have confirmed a positive 
influence of brand image (Kandampully \& Hu, 2007; Kandampully \& Suhartanto, 2000; Hsu et al., 2012; Martínez et al., 2014b) and brand awareness (Kayaman \& Arasli, 2007; Kim et al., 2008; Hyun \& Kim, 2011) on brand loyalty within the hospitality industry. Thus, the authors propose the following hypotheses:

$\mathbf{H}_{6}$ : Perceived quality has a positive impact on brand loyalty.

H7: Brand image has a positive impact on brand loyalty.

H8: Brand awareness has a positive impact on brand loyalty.

H9: Perceived quality has a positive impact on brand awareness.

INSERT FIGURE 1 ABOUT HERE

\section{Methodology}

\section{Data collection}

In order to design the research sample a non-probability sampling procedure was chosen. Specifically, a convenience sample was used as the researcher did not have access to a census of hotel clients over the age of 18 in the Autonomous Community of Cantabria (Spain) and it was not possible to determine the probability of any particular element of the population being chosen for the sample (Trespalacios, Vázquez \& Bello, 2005). However, to ensure greater representation of the data, a multistage sampling by quotas was made by characterizing the population according to two criteria: the gender and age of respondents. Thus, to test the proposed hypotheses empirically personal surveys were conducted among Spanish hotel consumers. A self-administered questionnaire was used to collect data from respondents.

Data collection was carried out in collaboration with university students of the University of Cantabria coursing their last academic year. Each student had to conduct surveys to several persons following specific patterns of gender and age. Students had to explain the purpose of the study and asked if respondents were willing to participate in the personally administered survey. Interviews were carried out in the respondents' homes to ensure their comfort and make sure that they took time to answer the questions calmly and thoughtfully. The length of each interview averaged 15 minutes to avoid fatigue in the respondents. Potential respondents also were required to answer a screening question to verify that they had stayed in a hotel carrying out CSR initiatives.

A total of 382 valid questionnaires were obtained after removing incomplete and inaccurate surveys. It must be highlighted that before conducting the fieldwork, the authors provided students specific instructions to carry out data collection (included the final questionnaire previously developed by the authors).

\section{Profile of respondents}


Table 1 displays the profile of the respondents. Female respondents accounted for $50.2 \%$ of the sample, whereas male respondents represented $49.8 \%$ (which is comparable to the population in Spain). $10 \%$ of the respondents were under the age of 24 , with $38.7 \%$ aged between 25 and 44 , and $51.3 \%$ being over the age of 45 . In terms of educational level $52.7 \%$ of the sample had an undergraduate degree, $20.3 \%$ a graduate degree and $18.9 \%$ a postgraduate degree.

\section{INSERT TABLE 1 ABOUT HERE}

\section{Measures}

The authors employed previously validated scales to measure perceptions of CSR and CBBE dimensions. CSR was measured using a three scale derived from Brown and Dacin (1997). Response options were anchored at 1 (strongly disagree) and 7 (strongly agree). Brand image was measured using a 6-item scale developed by Martínez, Montaner and Pina (2004). Perceived quality was measured using a 6-item scale adapted from Parasuraman, Zeithaml and Berry (1998). A 3-item scale by Yoo and Donthu (2001) was used to measure brand awareness. Brand loyalty was measured using a 4-item scale founded on Zeithaml, Berry and Parasuraman (1996) and Sirdeshmukh, Japdig and Berry (2002) measuring attitudinal and behavioral aspects (Appendix A).

Previous research shows that $\mathrm{CBBE}$ is a multidimensional construct. However, the role of awareness in the brand equity creation in the hotel context is questionable since some recent studies revealed that it is not a significant dimension of this construct (e.g., Kayaman \& Arasli, 2007; So \& King, 2010). Thus, the authors carried out first and second-order confirmatory factor analyses to gain a better understanding of the CBBE construct (Appendix B).

Our results confirm that $\mathrm{CBBE}$ is a second-order construct generated from the relationships among the subordinate factors of brand image, perceived quality, brand awareness and brand loyalty (67.167\% of variance explained). Figure 2 shows the final estimates of the second-order model. The goodness of fit indices (NFI, NNFI, CFI and IFI) exceeds or is very close to the minimum recommended value of 0.9 (Hair, Black, Babin \& Anderson, 2010). Consequently, it can be argued that the second-order model is acceptable. Additionally, the estimated coefficients for the four dimensions are positive and significant. Therefore these dimensions accurately represent the underlying concept of CBBE.

\section{INSERT FIGURE 2 ABOUT HERE}

\section{Measurement model}

This study employs Anderson and Gerbing's (1988) procedure of structural equation modelling. First, to test the psychometric properties of the measurement model a confirmatory factor analysis (CFA) was performed. Second, the structural relations 
among our constructs were analyzed through a structural equation model. The reliability of the scales was assessed through the Cronbach's alpha coefficient and the average variance extracted (AVE). All the estimated statistics were above the threshold of 0.7 and 0.5 (Hair et al., 2010) which indicated good internal consistency. Furthermore, the convergent validity of the model is established since all the items are significant $(p<0.05)$ and their standardized coefficients exceed 0.5 (Table 2) (Steenkamp \& Van Trijp, 1991). Finally, the authors employed the procedure developed by Fornell and Larcker (1981) to verify discriminant validity. Table 3 provides evidence for discriminant validity.

\section{INSERT TABLE 2 HERE}

\section{INSERT TABLE 3 HERE}

\section{Hypotheses testing}

Once the authors verified the psychometric properties of the measurement instrument, the structural equation model for the sample was tested. As can be seen in Table 4, the goodness of fit statistics showed the model fits the data. The overall fit of the model is acceptable with chi-square (310), NFI, TLI, CFI, IFI and RMSEA of 792.638, 0.856, $0.894,0.906,0.907$ and 0.063 , respectively. Furthermore the model explains $65.1 \%$ of the variance of the brand loyalty. Regarding the relationships among the constructs the authors found support for all the hypotheses (Table 4). In particular, positive and significance relationships are verified between CSR and customer-based equity dimensions: brand image $(\beta=0.288, \mathrm{p}<0.005)$, perceived quality $(\beta=0.470, p<0.005)$, brand awareness $(\beta=0.140, p<0.005)$, and brand loyalty $(\beta=0.151, p<0.005)$ thus, supporting $\mathrm{H}_{1}, \mathrm{H}_{2}, \mathrm{H}_{3}$ and $\mathrm{H}_{4}$.

In addition, positive and significant relationships between CBBE dimensions are observed. In particular, perceived quality has positive direct effects on brand image $(\beta=0.496, p<0.005)$, brand awareness $(\beta=0.600, p<0.005)$ and brand loyalty $(\beta=0.618$, $\mathrm{p}<0.005)$. Similarly, brand image has a positive and direct effect on brand loyalty $(\beta=0.216, p<0.005)$. Finally, brand awareness has a positive and direct effect on brand loyalty $(\beta=0.148, \mathrm{p}<0.005)$ thus supporting $\mathrm{H}_{5}, \mathrm{H}_{6}, \mathrm{H}_{7}, \mathrm{H}_{8}$ and $\mathrm{H}_{9}$.

\section{INSERT TABLE 4 ABOUT HERE}

INSERT FIGURE 3 ABOUT HERE

\section{Discussions and implications}

\section{Theoretical implications}

Previous research on CBBE applied Aaker's (1991) multidimensional framework comprised of brand image, perceived quality, brand awareness and brand loyalty. However, to the best of the authors' knowledge, any study has taken into consideration the effects of CSR in association with the formation of brand equity from customers' 
perspective. By filling this gap this research highlights several theoretical contributions. This study is the first one that proposes and confirms positive effects of guests' perceptions of CSR initiatives on antecedents of customer-based hotel brand equity. The findings presented here show a good model fit to the data, demonstrating significance and positive relations among CSR, brand image, perceived quality, brand awareness and brand loyalty. These results propose that the implementation of CSR strategies (and its subsequent perception by customers) can increase brand equity and provide hotel brands with competitive advantages. Secondly, this research expands previous studies on customer-based hotel brand equity by examining the links among equity dimensions. In doing so, this study sheds new light on the CBBE framework in that brand loyalty is enhanced through CSR initiatives. This implies that hotel managers should devote more resources to CSR practices because customers support those brands perceived as socially responsible by developing greatest levels of loyalty toward them. Furthermore, this study expands previous research by confirming the role of brand awareness as a CBBE dimension in the hospitality sector. Finally, the proposed model is tested from the consumer perspective, confirming the relevance of consumer perceptions as an integral part of corporate strategies and policies.

This research shows that guests' CSR perceptions can form strong and positive associations (e.g., brand awareness and image) while enhancing perceived quality and brand loyalty. These results extend previous studies in the hospitality context such as the paper by Namkung and Jang (2013). These authors found that the effects of green practices at restaurants on perceived quality and behavioral intentions were not significant. In their study, environmental initiatives enhance brand image and behavioral intentions but not perceived quality. The findings presented in this study reveal the relevance of CSR in the current hospitality sector and the need for hotel companies to include this concept in their branding strategies. This research demonstrates that CSR is a key strategic tool, given its essential role in building not only perceived quality and brand loyalty but also brand image and brand awareness.

Furthermore, these findings confirm that the four dimensions of CBBE are interrelated for hotel brands. Perceived quality is found to influence brand image, brand awareness and brand loyalty. In this sense, these results are consistent with the article by Chen and Myagmarsuren (2011) who demonstrate that perceived quality is one of the key strategic issues when establishing long-term relationships with customers. In particular, these findings show that the impact of perceived quality on brand awareness and brand loyalty are stronger than any other effect. These findings are in line with previous studies such as the paper by Seric et al. (2014) who identify perceived quality as the most relevant predictor of brand equity in the hotel industry. Similarly, Kwon and Lennon (2009) propose that in order to enjoy benefits of brand loyalty firms should achieve them through excellent service quality. Moreover, these results reveal that brand image and brand awareness affect brand loyalty in the hospitality industry as previous studies demonstrate (Kim et al., 2008; Hyun \& Kim, 2011; He \& Lai, 2014). 
This study also expands extant research by confirming the role of brand awareness as a CBBE dimension in the hospitality industry. To date, the role of awareness in brand equity creation within the hotel context remained unclear since previous research revealed that it was not a significant domain of brand equity. However, this research confirms that brand awareness is a significant construct affecting CBBE. This shows that the relationship between brand equity and customers' perceptions is different depending on the sector of hospitality industry (e.g., hotels, restaurants or casinos).

To conclude, this study sheds new light on the CBBE framework in that brand loyalty is enhanced through CSR. These findings extend previous studies such as the paper by He and Lai (2014) since this research not only corroborates a direct effect between CSR and brand loyalty but also demonstrates that there is a framework of relations among CBBE that allows understanding how customers build brand equity via CSR. As final conclusion, this study extend previous research arguing that the CBBE approach can be integrated with other theoretical perspectives to explore customers' responses toward companies in order to provide hotel brands with competitive advantages. This study demonstrates this position by designing and testing a general framework that integrates customer-based hotel brand equity and CSR approaches.

\section{Managerial implications}

The findings of this study suggest that hospitality businesses ought to consider brand image, perceived quality, brand awareness and brand loyalty when attempting to establish brand equity from the customers' perspective. First, hotel managers should emphasize the importance of CSR issues into their branding strategies by devoting additional financial and human resources to environmental and social campaigns so as to build up brand associations and subsequent brand equity. Specifically, hotels could implement CSR programs aimed at controlling the emission of pollutants to the atmosphere, reducing the consumption of water, protecting environmentally valuable habitats to preserve biodiversity, starting collaborations with local communities (e.g., purchases from local suppliers or forums to raise CSR awareness among residents), hiring employees with disabilities, donating resources to diverse social causes, providing information to guests relating to cultural tourism (e.g., monuments, museums and traditional festivals) or promoting cultural resources of destinations (e.g., handicraft, music...). By doing so, hotels can build an attractive CSR-based brand image.

Secondly, consumers are unlikely to respond to CSR practices if they do not perceive them. Since brand communications related to CSR issues might influence guests' perceptions of brand associations (e.g., brand image and brand awareness), perceived quality and brand loyalty, the authors recommend hotel managers to communicate and promote these initiatives effectively to explain the benefits of socially responsible activities and make consumers understand the goals of operating responsible hotels. Therefore, hoteliers are recommended to develop strategies to raise perceptions of CSR initiatives and help potential customers to be aware of these practices. In order to increase brand awareness related to CSR issues, hospitality firms should employ diverse channels 
such as annual reports, corporate websites, advertising, social networks or public relations.

Additionally, hospitality managers are recommended to develop specific programs to instruct employees on CSR issues as the delivery of a successful CSR-based brand relies on them. In the hospitality context, staff is a critical mediator actor who delivers information between managers and guests. Therefore, hoteliers should introduce innovative programs to ensure that members of staff are not only providing good service but also accurate information about the hotel's CSR strategy. It would also be possible for managers to create programs to involve customers in these activities. For instance, guests can reduce their energy or water consumption, recycle and donate a percentage of their bill to a cause supported by the hotel.

To conclude, this study has several limitations. First, the results of this research concern only the Spanish hotel context. The authors suggest future studies to approach different hotel segments (e.g., high-quality, mid-priced or budget places) in order to increase generalization of the findings. In a similar way, it would also be interesting to analyze differences among hospitality costumers participating on package programs and those customers who do not get the ability to choose the hotel. Moreover, additional variables could be included in the model. With regard to this, future studies could follow an integrated approach and combine different theoretical frameworks to include other CBBE dimensions such as brand meaning or brand satisfaction.

\section{Funding}

This research was funded by the FPU Scholarship Program provided by the Spanish Ministry of Education, Culture and Sports.

\section{References}

Aaker, D. A. (1991). Managing brand equity. New York, NY: The Free Press.

Aaker, D. A. (1996). Measuring brand equity across products and markets. California Management Review, 38(3), 102-120.

Aldás, J., Andreu, L., \& Currás, R. (2013). La responsabilidad social como creadora de valor de marca: El efecto moderador de la atribución de objetivos. Revista Europea de Dirección y Economía de la Empresa, 22(1), 21-28.

Anderson, J.C., \& Gerbing, D.W. (1988). Structural equation modelling in practice: A review and recommended two-step approach. Psychological Bulletin, 103(3), 411-423.

Ayuso, S. (2006). Adoption of voluntary environmental tools for sustainable tourism: Analysing the experience of Spanish hotels. Corporate Social Responsibility and Environmental Management, 13(4), 207-220. 
Bekk, M., Sp, M., Hedjasie, R., \& Kerschreiter, R. (2016). Greening the competitive advantage: antecedents and consequences of green brand equity. Quality and Quantity, 50(4), 1727-1746.

Ben, H.F., Ye, H., \& Law, R. (2014). You do well and I do well? The behavioral consequences of corporate social responsibility. International Journal of Hospitality Management, 40, 62-70.

Benavides-Velasco, C.A., Quintana-García, C., \& Marchante-Lara, M. (2014). Total quality management, corporate social responsibility and performance in the hotel industry. International Journal of Hospitality Management, 41, 77-87.

Bohdanowicz, P. (2006). Environmental awareness and initiatives in the Polish and Swedish hotel industries-survey results. International Journal of Hospitality Management, 25(4), 662-682.

Bohdanowicz, P., \& Zientara, P. (2008). Corporate social responsibility in hospitality: Issues and implications. A case study of Scandic. Scandinavian Journal of Hospitality and Tourism, 8(4), 271-293.

Bose, S., Roy, S. J., \& Tiwari, A. K. (2015). Measuring customer-based brand equity: an investment attractiveness perspective. Journal of Strategic Marketing, 24(7), 617-634.

Brown, T.J., \& Dacin, P.A. (1997). The company and the product: Corporate association and consumer product responses. Journal of Marketing, 61(1), 68-84.

Chen, C.F., \& Myagmarsuren,O. (2011). Brand equity, relationship quality, relationship value and customer loyalty: Evidence from the telecommunications services. Total Quality Management, 22(9), 957-974.

Çifci,S., Ekinci Y., Whyatt,G., Japutra, A., Molinillo,S., \& Siala, H. (2016). A cross validation of Consumer-Based Brand Equity models: Driving customer equity in retail brands. Journal of Business Research, 69(9), 3740-3747.

Chung, L.H., \& Parker, L.D. (2010). Managing social and environmental action and accountability in the hospitality industry: A Singapore perspective. Accounting Forum, 34(1), 46-53.

Creel, T. (2012). How corporate social responsibility influences brand equity. Management Accounting Quarterly, 13(4), 20-24.

De Grosbois, D. (2012). Corporate social responsibility reporting by the global hotel industry: Commitment, initiatives and performance. International Journal of Hospitality Management, 31(3), 896-905.

Denizci, B., \& Tasci, A. D. A. (2010). Modeling the commonly-assumed relationship between human capital and brand equity in tourism. Journal of Hospitality Marketing \& Management, 19(6), 610-628. 
Dev, Chekitan, S. (2012). Hospitality branding. New York, NY: Cornell University Press.

Dodds, R., \& Kuehnel, J. (2010). CSR among Canadian mass tour operators: Good awareness but little action. International Journal of Contemporary Hospitality Management, 22(2), 221-244.

Ernst \& Young (2014). Global hospitality insights: Top thoughts for 2014. Retrieved from: http://www.ey.com/Publication/vwLUAssets/EY__Global_hospitality_insights_2014/\$FILE/EY-Global-hospitality-insights-2014.pdf (accessed 05/02/2015).

Farquhar, P. (1989). Managing brand equity. Marketing Research, 1(3), 24-33.

Font, X., Walmsley, A., Cogotti, S., McCombes, L., \& Hausler, N. (2012). Corporate social responsibility: The disclosure-performance gap. Tourism Management, 33(6), 1544-1553.

Fornell, C., \& Larcker, D.F. (1981).Evaluating structural equation models with unobservable variables and measurement error. Journal of Marketing Research, 18(1), $39-50$.

Garay, L., \& Font, X. (2012). Doing good to do well? Corporate social responsibility reasons, practices and impacts in small and medium accommodation enterprises. International Journal of Hospitality Management, 31(2), 329-337.

Geerts, W. (2014). Environmental certification schemes: Hotel managers' view and perceptions. International Journal of Hospitality Management, 39, 87-96.

Gu, H., \& Ryan, C. (2011). Ethics and corporate social responsibility: An analysis of the views of Chinese hotel managers. International Journal of Hospitality Management, 30(4), 875-885.

Hair, J.F., Black, W.C., Babin, B.J., \& Anderson, R.E. (2010). Multivariate data analysis. Upper Saddle River, NJ: Pearson Prentice-Hall.

He, Y., \& Lai, K.K. (2014). The effect of corporate social responsibility on brand loyalty: The mediating role of brand image. Total Quality Management \& Business Excellence, 25(3), 249-263.

He, H., \& Li, Y. (2011). CSR and service brand: The mediating effect of brand identification and moderating effect of service quality. Journal of Business Ethics, 100(4), 673-688.

Henderson, J.C. (2007). Corporate social responsibility and tourism: Hotel companies in Phuket, Thailand, after the Indian Ocean tsunami. International Journal of Hospitality Management, 26(1), 228-239.

Herrmann, A., Huber, F., Shao, A., \& Bao, Y. (2007). Building brand equity via product quality. Total Quality Management, 18(5), 531-544. 
Holcomb, J. L., Upchurch, R. S., \& Okumus, F. (2007). Corporate social responsibility: What are top hotel companies reporting. International Journal of Contemporary Hospitality Management, 19(6), 461-475.

Holloway, C.J. (2004). Marketing for Tourism. Harlow: Prentice Hall.

Hsieh, Y. C. (2012). Hotel companies' environmental policies and practices: A content analysis of their web pages. International Journal of Contemporary Hospitality Management, 24(1), 97-121.

Hsu, T. H., Hung, L. C., \& Tang, J. W. (2012). An analytical model for building brand equity in hospitality firms. Annals for Operations Research, 195(1), 355-378.

Huang, Z., \& Cai, L. A. (2015). Modeling consumer-based brand equity for multinational hotel brands: When hosts become guests. Tourism Management, 46, 431-443.

Hur, W., Kim, H., \& Woo, J. (2014). How CSR leads to corporate brand equity: Mediating mechanisms of corporate brand credibility and reputation. Journal of Business Ethics, 125(1) 75-86.

Hyun, S.S., \& Kim, W. (2011). Dimensions of brand equity in the chain restaurant industry. Cornell Hospitality Quarterly, 52(4), 429-437.

Inoue, Y., \& Lee, S. (2011). Effects of different dimensions of corporate social responsibility on corporate financial performance in tourism-related industries. Tourism Management, 32(4), 790-804.

Jiang, W., Dev, C. S., \& Rao, V. R. (2002). Brand extension and customer loyalty: evidence from the lodging industry. Cornell Hotel and Restaurant Administration Quarterly, 43(4), 5-16.

Jones, R. (2005). Finding sources of brand value: Developing a stakeholder model of brand equity. Brand Management, 13(1), 10-32.

Jones, T., \& Taylor, S.F. (2007). The conceptual domain of service loyalty: How many dimensions? Journal of Services Marketing, 21(1), 36-51.

Kandampully, J., \& Suhartanto, D. (2000). Customer loyalty in the hotel industry: The role of customer satisfaction and image. International Journal of Contemporary Hospitality Management, 12(6), 346-351.

Kandampully, J., \& Hu, H. (2007). Do hoteliers need to manage image to retain loyal customers? International Journal of Contemporary Hospitality Management, 19(6), 435443.

Kandampully, J., Juwaheer, T., \& Hu, H. (2011). The influence of a hotel firm's quality of service and image and its effect on tourism customer loyalty. International Journal of Hospitality \& Tourism Administration, 12(1), 21-42. 
Kang, G., \& James, J. (2004). Service quality dimensions: An examination of Gronroos's service quality model. Managing Service Quality, 14(4), 266-277.

Kang, K., Lee, S., \& Huh, C. (2010). Impacts of positive and negative corporate social responsibility activities on company performance in the hospitality industry. International Journal of Hospitality Management, 29(1), 72-82.

Kayaman, R., \& Arasli, H. (2007). Customer based brand equity: Evidence from the hotel industry. Managing Service Quality, 17(1), 92-109.

Kennedy, S. (1977). Nurturing corporate images. European Journal of Marketing, 11(3), 120-164.

Keller, K. L. (1993). Conceptualizing, measuring, and managing customer-based brand equity. Journal of Marketing, 57(1), 1-22.

Keller, K. L. (1998). Strategic brand management: Building, measuring, and managing brand equity. Upper Saddle River, NJ: Prentice Hall.

Keller, K.L., \& Lehmann, D.R. (2006). Brands and branding: Research findings and future priorities. Marketing Science, 25(6), 740-759.

Khan, A.A., \& Manwani, D.T. (2013). Sustainability and corporate brand equity through corporate social responsibility initiatives. Asia Pacific Journal of Management \& Entrepreneurship Research, 2(2), 267-279.

Kim, H.B., Kim, W.G., \& An, J.A. (2003). The effect of customer-based brand equity on firms' financial performance. Journal of Customer Marketing, 20(4), 335-351.

Kim, H. B., \& Kim, W.G. (2005). The relationship between brand equity and firms' performance in luxury hotels and chain restaurants. Tourism Management, 26(4), 549560 .

Kim, W.G., \& Kim, H.B. (2004). Measuring customer-based restaurant brand equity: Investigating the relationship between brand equity and firms' performance. Cornell Hotel and Restaurant Administration Quarterly, 45(2), 115-131.

Kim, W.G., Jin-Sun, B., \& Kim, H.J. (2008). Multidimensional customer-based brand equity and its consequences in mid-priced hotels. Journal of Hospitality \&Tourism Research, 32(2), 235-254.

Kimpakorn, N., \& Tocquer, G. (2010). Service brand equity and employee brand commitment. Journal of Services Marketing, 24(5), 378-388.

Kucukusta, D., Mak, A., \& Chan, X. (2013). Corporate social responsibility practices in four and five-star hotels: Perspectives from Hong Kong visitors. International Journal of Hospitality Management, 34, 19-30. 
Kwon, W.S., \& Lennon, S. (2009). What induces online loyalty? Online versus offline brand images. Journal of Business Research, 62(5), 557-564.

Lee, J. W., \& Kim, H. B. (2009). Impacts of perception to alliance companies on hotel's brand equity according to the types of vertical integration. International Journal of Tourism Sciences, 9(2), 1-21.

Lee, S., \& Park, S.Y. (2009). Do socially responsible activities help hotels and casinos achieve their financial goals? International Journal of Hospitality Management, 28(1), 105-112.

Lee, S., Singal, M., \& Kang, K. (2013). The corporate social responsibility-financial performance link in the U.S. restaurant industry: Do economic conditions matter? International Journal of Hospitality Management, 32, 2-10.

Liu, M.T., Wong, I. A., Rongwei, C., \& Tseng, T. H. (2014). Do perceived CSR initiatives enhance customer preference and loyalty in casinos? International Journal of Contemporary Hospitality Management, 26(7), 1024 -1045.

Malik, M.E., \& Naeem, B. (2011). Interrelationship between customer based brand equity constructs: Empirical evidence from hotel industry of Pakistan. Interdisciplinary Journal of Contemporary Research in Business, 3(4), 795-804.

Marin, L., Ruiz, S., \& Rubio, A. (2009). The role of identity salience in the effects of corporate social responsibility on consumer behavior. Journal of Business Ethics, 84(1), $65-78$.

Martínez, P., \& Rodríguez del Bosque, I. (2013). CSR and customer loyalty: The roles of trust, customer identification with the company and satisfaction. International Journal of Hospitality Management, 35, 89-99.

Martínez, P., Pérez, A., \& Rodríguez del Bosque, I. (2014a). Exploring the role of CSR in the organizational identity of hospitality companies: A case from the Spanish tourism industry. Journal of Business Ethics, 124(1), 47-66.

Martínez, P., Pérez, A., \& Rodríguez del Bosque, I. (2014b). CSR influence on hotel brand image and loyalty. Academia Revista Latinoamericana de Administración, 27(2), 267-283.

Martínez, E., Montaner, T., \& Pina, J.M. (2004). Propuesta de una metodología. Medición de la imagen de marca. Un estudio exploratorio. Esic-Market, 117, 199-216.

McWilliams, A., \& Siegel, D. (2001). Corporate social responsibility: A theory of the firm perspective. The Academy of Management Review, 26(1), 117-127.

McWilliams, A., Siegel, D., \& Wright, P. (2005). Corporate social responsibility: Strategic implications. Rensselaer Working Papers in Economics. 
Namkung, Y., \& Jang, S. (2013). Effects of restaurant green practices on brand equity formation: Do green practices really matter? International Journal of Hospitality Management, 33, 85-95.

Nicolau, J. L. (2008). Corporate social responsibility: Worth-creating activities. Annals of Tourism Research, 35(4), 990-1006.

Nyahunzvi, D. K. (2013). CSR reporting among Zimbabwe's hotel groups: A content analysis. International Journal Contemporary Hospitality Management, 25(4), 595-613.

Parasuraman, A., Zeithaml, V.A., \& Berry, L.L. (1988). SERVQUAL: a multiple item scale for measuring customer perception of service quality. Journal of Retailing, 64(1), $12-37$.

Park, S.Y., \& Lee, S. (2009). Financial rewards for social responsibility: A mixed picture for restaurant companies. Cornell Hospitality Quarterly, 50(2), 168-179.

Park, S. Y., \& Levy, S. E. (2014). Corporate social responsibility: Perspectives of hotel frontline employees. International Journal of Contemporary Hospitality Management, 26(3), 332-348.

Prasad, K., \& Dev, C.S. (2000). Managing hotel brand equity: A customer-centric framework for assessing performance. Cornell Hotel and Restaurant Administration Quarterly, 41(3), 22-31.

Perez, A., García de los Salmones, M.M., \& Rodríguez del Bosque, I. (2012), The effect of corporate associations on consumer behavior. European Journal of Marketing, 47(1), 218-238.

Raub, S., \& Blunschi, S. (2014). The power of meaningful work: How awareness of CSR initiatives fosters task significance and positive work outcomes in service employees. Cornell Hospitality Quarterly, 55(1), 10-18.

Seric, M., \& Gil-Saura, I. (2012). ICT, IMC, and brand equity in high-quality hotels of Dalmatia: An analysis from guest perceptions. Journal of Hospitality Marketing\& Management, 21(8), 821-851.

Seric, M., Gil-Saura, I., \& Ruiz-Molina, M.E. (2014). How can integrated marketing communications and advanced technology influence the creation of customer-based brand equity? Evidence from the hospitality industry. International Journal of Hospitality Management, 39, 144-156.

Servaes, H., \& Tamayo, A. (2013). The impact of corporate social responsibility on firm value: The role of customer awareness. Management Science, 59(5), 1045-1061.

Shobri, M., Diyana, N., \& Lennora, P. (2015). Building guest loyalty: The role of guest based brand equity and guest experience in resort hotel industry. Advanced Science Letters, 21(5), 1605-1609. 
Singal, M. (2014). The link between firm financial performance and investment in sustainability initiatives. Cornell Hospitality Quarterly, 55(1), 19-30.

Sirdeshmukh, D., Japdig, S., \& Berry, S. (2002). Customer trust, value, and loyalty in relational exchanges. Journal of Marketing, 66(1), 15-37.

So, K., \& King, C. (2010). When experience matters: Building and measuring hotel brand equity. International Journal of Contemporary Hospitality Management, 22(5), 589-608.

Steenkamp, J.B., \& van Trijp, H.C.M. (1991). The use of LISREL in validating marketing constructs. International Journal of Research in Marketing, 8(4), 283-299.

Swimberghe, K.R., \& Wooldridge, B. R. (2014). Drivers of customer relationships in quick-service restaurants the role of corporate social responsibility. Cornell Hospitality Quarterly, 55(4), 354-364.

Tian, Z., Wang, R., \& Yang, W. (2011). Consumer responses to corporate social responsibility (CSR) in China. Journal of Business Ethics, 101(2), 197-212.

Trespalacios, J. A., Vázquez, R., \& Bello, L. (2005). Investigación de mercados [Market research]. Madrid: Thomson.

Tsai, H., Cheung, C., \& Lo, A. (2010). An exploratory study of the relationship between customer-based casino brand equity and firm performance. International Journal of Hospitality Management, 29, 754-757.

Tsai, H., Tsang, N., \& Cheng, S. (2012). Hotel employees' perceptions on corporate social responsibility: The case of Hong Kong. International Journal of Hospitality Management, 31(4), 1143-1154.

Wang, C.J. (2014). Do ethical and sustainable practices matter?: Effects of corporate citizenship on business performance in the hospitality industry. International Journal of Contemporary Hospitality Management, 26(6), 930-947.

Wang, D.H., Chen, P.H., Yu, T., \& Hsiao, C. (2015). The effects of corporate social responsibility on brand equity and firm performance. Journal of Business Research, 68(11), 2232-2236.

Wells, V.K., Manikab, D., Gregory-Smith, D., Taherid, B., \& McCowlene, C. (2015). Heritage tourism, CSR and the role of employee environmental behavior. Tourism Management, 48, 399-413.

Wong, T., \& Wickham, M. (2014). An examination of Marriott's entry into the Chinese hospitality industry: A brand equity perspective. Tourism Management, 48, 439-454.

$\mathrm{Xu}$, J. B., \& Chan, A. (2010). A conceptual framework of hotel experience and customersbased brand equity. International Journal of Contemporary Hospitality Management, 22(2), 174-193. 
$\mathrm{Xu}, \mathrm{Y}$. (2014). Understanding CSR from the perspective of Chinese diners: The case of McDonald's. International Journal of Contemporary Hospitality Management, 26(6), 1002-1020.

Yesawich, P. C. (1996). So many brands, so little time. Lodging Hospitality, 52(9), 1624.

Yoo, B., \& Donthu, N. (2001). Developing and validating a multidimensional consumerbased brand equity scale. Journal of Business Research, 52(1), 1-14.

Yoo, B., Donthu, N., \& Lee, S. (2000). An examination of selected marketing mix elements and brand equity. Academy of Marketing Science, 28(2), 195-211.

Zeithaml, V.A., Berry, L.L., \& Parasuraman, A. (1996). The behavioral consequences of service quality. Journal of Marketing, 60(2), 31-46.

Zhang, L. (2014). How effective are your CSR messages? The moderating role of processing fluency and construal level. International Journal of Hospitality Management, $41,56-62$.

\author{
INSERT HERE APPENDIX A \\ INSERT HERE APPENDIX B
}

